\title{
WZORY PRZEMYSŁOWE MIĘDZY SCYLLĄ A CHARYBDĄ
}

\author{
Zaprzeczeniem ducha twórczości jest design jako przedsięwzięcie \\ rynkowe, jako działanie kalkulowane z myśla o odbiorcach, \\ powodowane pragnieniem powodzenia, sukcesu... Niestety, wielu \\ artystów wspótczesnych kieruje się podobnymi motywami. \\ J. Krupiński, Filozofia a sztuka \\ (,Wiadomości ASP” 2014, nr 64, s. 28)
}

\section{WSTĘP}

Wzornictwo przemysłowe ${ }^{1}$ (określane coraz powszechniej mianem designu/ dizajnu $^{2}$ ) jako rezultat kreatywności człowieka wciąż poszukuje swego miejsca w prawie własności intelektualnej. O ile w XIX w. podejmowano próby znalezienia najbardziej właściwej formy ochrony rezultatów twórczości intelektualnej w tej dziedzinie, o tyle XX w. zaowocował ich nadmiarem ${ }^{3}$. Początek XXI w. pokazuje, że nadszedł czas na swego rodzaju oczyszczenie. Impulsem do rozważań na temat potrzeby zweryfikowania pewnych koncepcji i utartych metod interpretacji są wydane w ostatnim czasie wyroki Sądu Najwyższego i Naczelnego Sądu Admnistracyjnego dotyczące ochrony wzorów przemysłowych w reżimie prawnoautorskim i reżimie wzorniczym, które odczytuję jako zagrożenie racjonalności ochrony rezultatów twórczości tego rodzaju w prawie własności intelektualnej.

Właściwa identyfikacja przedmiotu ochrony i jego przyporządkowanie do odpowiedniego reżimu stanowią kluczowy problem prawa własności intelektu-

${ }^{1}$ Wielka encyklopedia PWN (t. 30, Warszawa 2005) definiuje wzornictwo przemysłowe jako „projektowanie wzorów wyrobów przeznaczonych do masowej produkcji, którego celem jest rozwijanie kultury materialnej społeczeństwa przez podnoszenie estetyki wytwarzanych przemysłowo przedmiotów codziennego użytku".

${ }^{2}$ Spolszczona pisownia angielskiego pojęcia design coraz częściej pojawia się w literaturze polskiej dotyczacej wzornictwa przemysłowego. Zob. więcej A. Cieślikowa, Design czy dizajn?, „Kwartalnik 2+3D” 2001, nr 1(IV), s. 8. Zob. np. V. Papanek, Dizajn dla realnego świata, Łódź 2012.

${ }^{3}$ Co trafnie ujał G. Dinwoodie (The Death of Ontology: A Teleological Approach to Trademark Law, „Iowa Law Review” 84, 1999, s. 678): „Design is ubiquitous, inhabiting all major intellectual property regimes, including copyright law”. 
alnej. Procesowi temu powinno przyświecać pytanie, w czym wyraża się istota twórczości intelektualnej w danej dziedzinie i jakie cele realizuje jej ochrona. Prawo własności intelektualnej jako całość chroni - co do zasady - rezultaty działalności człowieka, które zbiorczo można określić mianem twórczości intelektualnej w różnych dziedzinach ${ }^{4}$. Niezależnie od rozmaitości dziedzin, w których objawia się kreatywność człowieka (techniki, sztuki), jedną z cech konstytuujących pojęcie twórczości jest nowość rezultatu kreacji ${ }^{5}$. Twórczość definiowana jest bowiem jako działanie prowadzace do powstania czegoś nowego, a więc czegoś innego od rzeczy zastanych lub czegoś, czego wcześniej nie było ${ }^{6}$.

Następnie w ramach analizy, czy rezultat twórczości powinien podlegać ochronie w jednym z reżimów własności intelektualnej, odmienność (inność) wytworu intelektualnego na tle wytworów istniejacych, poddawana jest ocenie jakościowej (wartościującej, aksjologicznej) ${ }^{7}$. Ten drugi etap patrzenia na nowość kreacji może być podstawą jej rozmaitego przyporządkowania do reżimów ochrony własności intelektualnej ${ }^{8}$, szczególnie wówczas gdy różnica ontologiczna między przedmiotem ochrony nie jest tak wyraźna (jak ma to miejsce w przypadku wzorów przemysłowych i utworów). Znaczenie (ocena jakościowa) nowości wytworu intelektualnego zależy w zasadniczej mierze od jego percepcji. Tu pojawia się problem modelowego odbiorcy, który w zależności od tego, jaką wartość ma reprezentować nowość kreacji podlegającej ochronie w określonej formie, odznacza się innymi przymiotami i na inne cechy zwraca uwagę. W konsekwencji prawo własności intelektualnej dysponuje galeria typów normatywnych - modeli skrojonych na potrzebę oceny wartości nowości wytworów intelektualnych (od normalnego odbiorcy, poprzez przeciętnego konsumenta, zorientowanego użytkownika, aż po znawcę-specjalistę).

Wszystkie omawiane niżej wyroki dotyczą kryteriów ochrony - prawnoautorskiej i wzorniczej, które ze względu na członkowstwo Polski w UE powinny być interpretowane $\mathrm{z}$ uwzględnieniem prawa i orzecznictwa unijnego.

${ }^{4}$ Wyłom stanowią tu oznaczenia (znaki towarowe).

5 Tak A. Wojciechowska (Wzornictwo przemystowe - zagadnienie przedmiotu ochrony prawnej, Zeszyty Naukowe Uniwersytetu Jagiellońskiego. Prace z Wynalazczości i Ochrony Własności Intelektualnej, z. 54, Kraków 1990, s. 50) z powołaniem na wypowiedzi W. Stróżewskiego, Dialektyka twórczości, Kraków 1983, s. 37.

${ }^{6}$ W. Stróżewski, op. cit., s. 13. Jak trafnie zauważa A. Wojciechowska (op. cit., s. 52, przyp. 10), analizując fenomen nowości, nie sposób oddzielić aspekt różnicy od aspektu pojawienia się w rzeczywistości czegoś nowego.

7 Zob. A. Wojciechowska, op. cit., s. 54: „Wprowadzona zmiana musi reprezentować jakąśs wartość". Autorka powołuje się na definicję twórczości, zgodnie z którą twórczością jest proces przynoszący nowy wytwór, oceniany w określonym czasie przez grupę jako trafny lub użyteczny. Ten drugi człon definicji stanowi, zdaniem autorki, „moment aksjologiczny (wartościowanie: trafny lub użyteczny)”.

${ }^{8} \mathrm{Na}$ całość systemu ochrony własności intelektualnej, a więc dziedziny prawa, która z założenia przeznaczona jest do ochrony różnych przejawów ludzkiej kreatywności, można spojrzeć w sposób uproszczony przez pryzmat zależności między wymaganym do przyznania ochrony nasileniem kreatywności (ocenianej przez pryzmat nowości wytworu) a zakresem ochrony. Im bardziej wygórowane są wymogi względem poziomu twórczości, tym szerszy i mocniejszy jest charakter ochrony. Taką zależność zdaje się dostrzegać m.in. J. du Mont, Creativity in Designs [w przygotowaniu]. 
Tymczasem oba reżimy, wykorzystywane do ochrony różnych przejawów twórczości intelektualnej w sposób, jaki zdają się to sugerować te wyroki, moga być porównane do mitologicznych potworów morskich, które czatowały po obu brzegach Cieśniny Mesyńskiej na nieświadomych niebezpieczeństwa żeglarzy.

\section{REŻIM WZORNICZY JAKO SCYLLA ${ }^{9}$}

Zasady ochrony wzorów przemysłowych w reżimie sui generis, tj. w Polsce prawem z rejestracji wzoru przemysłowego, nie stanowią domeny prawa krajowego $\mathrm{w}$ tym sensie, że określony w art. 102-119 p.w.p. ${ }^{10}$ model ochrony wzorów przemysłowych powinien stanowić odwzorowanie unijnej konstrukcji sformułowanej w dyrektywie 98/71/WE ${ }^{11}$. Założeniem unijnego prawodawcy było bowiem nie tyle „równanie” krajowych zasad ochrony wzorów, ile raczej „narzucenie” państwom członkowskim jednego spójnego, opartego na tych samych założeniach konstrukcyjnych i uzasadnieniu, modelu ochrony. Tymczasem, co dowodnie potwierdza wyrok NSA z 15 stycznia 2014 r. (II GSK $1625 / 12)^{12}$, zarówno polski ustawodawca, jak i orzecznictwo przyswoili model unijny tylko połowicznie, bardzo powierzchownie, bez zrozumienia jego istoty. W tym wyroku, dotyczącym kwestii podstawowej, tj. kryteriów ochrony prawem z rejestracji wzoru przemysłowego, ale i we wcześniejszym wyroku SN z 23 października 2007 r. (II CSK 302/07) ${ }^{13}$, uwidoczniło się niezrozumienie unijnych założeń ochrony.

W sprawie II GSK 1625/12 na poszczególnych etapach rozstrzygania sporu zarysowały się dwie odmienne wizje relacji między przesłankami ochrony wzorów przemysłowych prawem z rejestracji. Ich weryfikacja przez UPRP doprowadziła ten organ do przekonania, że skoro sporny wzór przemysłowy nie miał cechy nowości, to tym samym nie było konieczne badanie indywidualnego charakteru wzoru, co spowodowało, że UPRP już na pierwszym etapie zakończył analizę spełnienia przesłanek ochrony. Tymczasem sądy administracyjne w kontradykcji do poglądu UPRP, przyjęły w tej sprawie, że „nie jest możliwe dokonanie oceny nowości bez przeprowadzenia oceny indywidualnego charakteru” ${ }^{14}$. Zdaniem NSA „nowość wzoru mieści się w pojęciu indywidual-

\footnotetext{
${ }^{9}$ Scylla (Skýlla) według mitologii greckiej była potworem morskim, hybryda - w połowie kobieta, w dolnej części wyrastało z jej ciała sześć wściekłych psów pożerających tych żeglarzy, których zdołały dosięgnąć.

${ }^{10}$ Ustawa z 30 czerwca 2000 r. - Prawo własności przemysłowej, t.jedn. Dz. U. 2003, Nr 119, poz. 1117 ze zm. (dalej jako: p.w.p.).

${ }^{11}$ Dyrektywa 98/71/WE Parlamentu Europejskiego i Rady z 13 października 1998 r. w sprawie prawnej ochrony wzorów, Dz. Urz. UE L z 28 października 1998 r., L 289/28 (dalej jako: dyrektywa 98/71/WE).

${ }^{12} \mathrm{~W}$ sprawie tej ogniskuja się elementarne problemy ochrony wzorów przemysłowych prawem z rejestracji. Zob. też wyrok WSA w Warszawie w tej sprawie z 11 czerwca 2012 r., VI SA/ Wa 2089/11.

${ }^{13}$ OSP 2009, nr 6, poz. 66.

${ }^{14}$ Uderzające sa wypowiedzi WSA w Warszawie (zob. przyp. 12) w tej sprawie: „W ocenie Sądu okoliczność, że ustawodawca w odrębnych normach art. 103 ust. 1 i w art. 104 ust. 1 i 2 p.w.p., określił szczegółowo przesłanki nowości i indywidualnego charakteru, ale to nie oznacza, że nowość wzoru można badać - jak w niniejszej sprawie - nie tylko w oderwaniu, ale i z pomi-
} 
nego charakteru”, z kolei „brak nowości - to brak indywidualnego charakteru i odwrotnie" 15 .

W procesie budowania nowego europejskiego modelu sui generis ochrony wzorów przemysłowych rozważano różne kryteria jako relewantne dla tego na nowo formowanego reżimu - nowość, oryginalność, odróżniający charakter, swoistość. Ostatecznie zdecydowano się na dwa - nowość i indywidualny charakter, które muszą być spełnione kumulatywnie. Podkreślano, że przyjęcie jednej przesłanki ochrony (nowości lub oryginalności) mogłoby niedostatecznie zuniformizować prawo w UE, gdyż państwa członkowskie nadal stosowałyby utarte przez lata podejście interpretacyjne.

Wymóg nowości wprowadzony został do reżimu wzorniczego jako kryterium typowe dla reżimów chroniących własność przemysłową na podstawie wpisu do rejestru, który ma stanowić źródło informacji, pewności prawa, ale i inspiracji dla projektantów. W świetle art. 4 dyrektywy 98/71/WE wzór jest nowy, jeżeli identyczny wzór nie został udostępniony publicznie przed datą zgłoszenia lub datą pierwszeństwa. Wzory sa identyczne, jeżeli ich cechy różnią się jedynie w nieistotnych szczegółach. Nowość wzoru występuje więc wówczas, gdy wzór jest nieznany oraz gdy różni się od innych - nie jest identyczny. Identyczność, oceniana na potrzeby weryfikacji nowości, „poddawana jest ścisłej ocenie, oderwanej od roli zorientowanego użytkownika w ocenie indywidualnego charakteru ${ }^{16}$ ". Weryfikacja nowości przez organ rozpatrujaccy (sąd, UP) powinna w większości przypadków być oczywista, gdyż ocena jest obiektywna. Nie potrzeba się w tej kwestii posiłkować ocena przez pryzmat jakiegokolwiek modelu normatywnego (specjalisty czy odbiorcy, który oceni wartość tych różnic). W rozstrzygnięciu powinny zostać wyłowione różnice między wzorami, które następnie należy poddać ocenie z punktu widzenia istotności, przy czym oceniający powinien wyjaśnić, dlaczego różnice w jego ocenie dotyczą nieistotnych cech.

Drugi wymóg, tj. indywidualny charakter wzoru przemysłowego, wskazuje na specyficzny przedmiot ochrony, która zapewniana jest przez wzgląd na marketingowe (rynkowe) znaczenie wzorów. Stwierdzany jest on wówczas, gdy ogólne wrażenie, jakie wzór wywołuje na zorientowanym użytkowniku, różni się od ogólnego wrażenia wywoływanego na nim przez wzór wcześniej udostępniony publicznie. Reżim wzorniczy zaprojektowany jest dla ochrony rezultatów działalności twórczej polegającej na projektowaniu postaci wytworu,

nięciem badania indywidualnego charakteru porównywanych wzorów. [...] „Przepis art. 103 ust. 1 p.w.p. odnoszący się do nowości używa określenia »identyczny wzór« co oznacza, że zarzut braku nowości może być postawiony dopiero po porównaniu obu wzorów, czy nie są identyczne, a to oznacza badanie indywidualnego charakteru, o którym mowa w art. 104 ust. 1 i 2 p.w.p.".

${ }^{15}$ Podobnie wcześniej - moim zdaniem nietrafnie - NSA w wyroku z 7 maja 2008 r., II GSK 232/08, w którym stwierdził jednoznacznie, że „nie jest możliwe dokonanie oceny nowości bez przeprowadzenia oceny indywidualnego charakteru tego wzoru. [...] Wzór przemysłowy może być uznany za niespełniający wymagania nowości tylko wówczas, gdy różni się nieistotnymi szczegółami od wzoru wcześniejszego, a więc jeżeli nie ma indywidualnego charakteru. W takim przypadku nie jest możliwe dokonanie oceny nowości bez przeprowadzenia oceny indywidualnego charakteru tego wzoru".

${ }^{16}$ Tak D. Stone, European Union Design Law, Oxford 2012, s. 135. 
która różni się od wcześniej znanych wzorów przemysłowych w sposób istotny dla rynku. Wyłączność w formie prawa z rejestracji jest przyznawana dlatego, że projektant wniósł coś istotnego, co jest rozpoznawalne (zauważalne) na rynku przez zorientowanego użytkownika; postrzegane przez niego jako swoiste, odmienne od tego, co było na rynku dotychczas, przykuwające uwagę. Stopień wkładu twórczego projektanta wzoru może być uwzględniany jedynie pośrednio przy ocenie użytku uczynionego przezeń z dostępnego zakresu swobody twórczej i tylko z perspektywy wpływu na ogólne wrażenie wywoływane przez wzór na zorientowanym użytkowniku.

Nowość i indywidualny charakter stanowią dwa niezależne wymogi, które muszą być spełnione kumulatywnie, jednakże powinny być odmiennie oceniane $^{17}$. W praktyce, ze względu na to, że oba wymogi oscylują wokół różnicy względem tego, co zastane, ich zakresy mogą krzyżować się do pewnego stopnia. Nie zwalnia to jednak organów weryfikujacych ich spełnienie od przeprowadzenia dwóch niezależnych testów. Wszystkie identyczne wzory będą wywierać takie samo ogólne wrażenie na zorientowanym użytkowniku. Jeżeli natomiast dwa wzory wywołują odmienne ogólne wrażenie, znaczy to, że nie są identyczne.

W literaturze krytykowano, że test nowości nie wnosi nic szczególnego stanowi właściwie mniej rygorystyczny wymóg w odniesieniu do tego samego aspektu (tj. różnicy). Wzory identyczne już nie muszą być oceniane przez pryzmat odbioru ich ogólnego wrażenia przez zorientowanego użytkownika. W dwustopniowej weryfikacji przesłanek ochrony wzornictwa przemysłowego dostrzec można cechę ekonomii procesowej - po co odnosić się do modelu normatywnego zorientowanego użytkownika, jeżeli już na wcześniejszym etapie gołym okiem - możemy coś rozstrzygnąć. To téz daje pewną sugestię interpretacyjną - różnice w nieznaczących szczegółach nie wystarczają do stwierdzenia indywidualnego charakteru. W praktyce jednak zwykle podnoszony jest brak obu przesłanek. Zaprezentowany w omawianej sprawie przez NSA brak dyscypliny w podejściu do obu przesłanek jest bardzo niepokojący. Relacje między obu przesłankami ochrony wzorów przemysłowych można ujaćc w następujące zależności: stwierdzenie indywidualnego charakteru wzoru przesądza, że wzór jest również nowy; brak nowości przesądza o braku indywidualnego charakteru, ale brak indywidualnego charakteru nie musi oznaczać jednoczesnego braku nowości.

17 Zob. decyzję Izby Odwoławczej OHIM z 11 sierpnia 2009 r. w sprawie R 887/2008-3 (Normann v Paton) - cedzak: „Oczywiście, jeżeli dwa wzory są identyczne, z zastrzeżeniem nieistotnych różnic, wówczas wywołują to samo ogólne wrażenie na zorientowanym użytkowniku. Jest równie oczywiste, że jeżeli dwa wzory wywołują odmienne ogólne wrażenie na zorientowanym użytkowniku, to nie mogą być identyczne. Mimo krzyżowania się nowości i indywidualnego charakteru, oba wymogi wykazują różnice. [...] Obszarem, w odniesieniu do którego mogą powstać wątpliwości interpretacyjne, jest pojęcie nieistotnych różnic. [...] w ramach oceny nowości [...] nie jest uzasadnione odwoływanie się do odbioru zorientowanego użytkownika. To indywidualny charakter wzoru [...] powinien być oceniany przez odwołanie do tego modelu. W przypadku nowości rozporządzenie nie wskazuje osoby, która mogłaby być punktem odniesienia w ocenach (ang. reference person). Ocena różnic w tym kontekście stanowi zadanie Urzędu”. 
Sąd Najwyższy w wyroku z 23 października 2007 r. (II CSK 302/07) ${ }^{18}$ odniósł się do podstawowych pojęć i koncepcji nowego zunifikowanego modelu ochrony wzorów przemysłowych. W części wprowadzającej uzasadnienia wyroku podkreślił konieczność nowego spojrzenia na kryteria ochrony wzorów prawem z rejestracji, prezentując poglądy zbieżne $\mathrm{z}$ unijną wizją istoty tej ochrony. Wywody te kończy jednak zaskakująca konkluzja, która dowodzi niezrozumienia istoty przesłanki indywidualnego charakteru i roli normatywnego modelu zorientowanego użytkownika. Zdaniem SN: „[n]ie ulega wątpliwości, że wybitny specjalista ma odpowiednie kwalifikacje do wypowiadania się w przedmiocie ogólnego wrażenia, jakie na zorientowanym użytkowniku wywołują porównywane wzory przemysłowe, gdyż każdy specjalista jest zorientowanym użytkownikiem w rozumieniu art. 105 ust. 4 p.w.p., choć nie każdy zorientowany użytkownik jest $\mathrm{w}$ danej dziedzinie specjalista zdolnym wydać opinię w tym przedmiocie jako biegły sądowy". Sąd błędnie zrównał perspektywę odbioru w różnych reżimach, tj. zorientowanego użytkownika i specjalisty z dziedziny wzornictwa przemysłowego, co okazało się brzemienne w skutki dla rozstrzygnięcia sporu ${ }^{19}$. Sprawa ta ilustruje problem niezrozumienia istoty oceny jakości twórczości w reżimie wzorniczym. Sąd powinien był w tej sprawie odkodować cechy zorientowanego użytkownika produktu ucieleśniającego sporny wzór. Ze względu na normatywny charakter tego modelu sąd co do zasady sam powinien podjać się rozstrzygnięcia o indywidualnym charakterze wzoru ${ }^{20}$. Opinia biegłego - specjalisty w dziedzinie projektowania wzorów przemysłowych mogłaby być sądowi pomocna jedynie w ustaleniu zakresu swobody twórczej. Tego rodzaju wypowiedź płynąca z sądu ostatniej instancji stanowi mylący drogowskaz dla wszystkich, którzy uczą się poruszać po no-

${ }_{18}$ OSN 2008, nr B, poz. 52, z glosą M. Poźniak-Niedzielskiej, OSP 2009, nr 6, poz. 66.

${ }_{19}$ Por. też częściowo krytycznie M. Poźniak-Niedzielska w glosie do ww. wyroku SN z 23 października 2007 r., s. 457-458, krytycznie też L. Brancusi, Wzór wspólnotowy i jego zakres ochrony, Warszawa 2012, s. 249-251. Por. też wyrok SO w Warszawie Wydział XXII - Sądu Wspólnotowych Znaków Towarowych i Wzorów Przemysłowych z 8 października 2007 r. (XXII GWwp 2/05, niepubl.), w którym Sąd stwierdził, że: „zorientowany użytkownik, którym jest osoba zainteresowana, obeznana $\mathrm{z}$ wystrojem i wyposażeniem wielu wnętrz, przebywajaca w nich i obserwujaca z większą niż przeciętna uwaga, przez dłuższy czas. Nie dokonuje ona jednak szczegółowych pomiarów, ani porównań. Postrzega wzór i przeciwstawiony mu produkt w sposób ogólny, jako całości, które są do siebie podobne. [...] Taki zorientowany użytkownik będzie osobą [...] znająca ofertę producentów tego typu przedmiotów, potrafiącą ocenić ich przydatność (funkcję techniczna) i zaobserwować i porównać ich wygląd ogólny kształty, linie, kontury”. W tej sprawie Sąd, wskazując niewielką przydatność opinii fachowców z zakresu wzornictwa przemysłowego, stwierdził, że przy ocenie „musiał jednak uwzględnić fakt, że dobrze poinformowany użytkownik nie ma ani ich wiedzy, ani doświadczenia. Jego postrzeganie wzoru i produktu jest z pewnością mniej wnikliwe i szczegółowe".

${ }^{20}$ Zob. wyrok SO w Warszawie, Sąd Wspólnotowych Znaków Towarowych i Wzorów Przemysłowych z 29 listopada 2010 r. (XXII GWwp 14/10, niepubl.), w którym Sąd podkreśla, że jego kompetencje w zakresie oceny ogólnego wrażenia wywoływanego przez wzór nie mogą być cedowane na biegłego. Jak wskazuje Sąd: „w polskim procesie cywilnym, biegły - specjalista w zakresie wzornictwa przemysłowego, nie może być utożsamiany ze zorientowanym użytkownikiem [...]. Równocześnie, nie może on wydawać opinii w imieniu innej osoby, a tym bardziej dokonywać oceny z punktu widzenia modelowej postaci o określonych ogólnie cechach, która wymaga zdefiniowania przez sąd w każdej konkretnej sprawie, z pewnościa jednak nie jest ona ekspertem ani znawca, nie ma jego wiedzy ani doświadczenia zawodowego". 
wym reżimie wzorniczym. Tak interpretowane zasady ochrony wzorów przemysłowych w reżimie sui generis jawią się nam jako Scylla, której atrakcyjna postać kobieca łączyła się z łbami kąsających psów. Niejeden, którego uwagę przyciagnie uroda tego reżimu, niespodziewanie może zostać pokąsany.

\section{REŻIM PRAWNOAUTORSKI JAKO CHARYBDA ${ }^{21}$}

Prawo autorskie umiejscawia wzornictwo przemysłowe pod szyldem sztuki użytkowej ${ }^{22}$, która tradycyjnie już przeciwstawiana jest sztukom pięknym $^{23}$. Pojęcie sztuki użytkowej jako antonim sztuk pięknych jest dzieckiem XIX-wiecznego myślenia o sztuce, które bazowało na rozdziale piękna i użyteczności. Tym, co odróżnia sztukę użytkową od sztuki „absolutnej” (od sztuk pięknych jako takich) w tym dychotomicznym ujęciu, jest jej przeznaczenie, związek z przedmiotami, które mają określoną funkcję, mają przypisany konkretny użytkowy cel, a więc egzystencję do pewnego stopnia niezależną od inkorporowanego do nich dzieła sztuki. Trzeba jednak pamiętać, że piękno i użyteczność nie zawsze były antytezą ${ }^{24}$, również współcześnie przestały być tak postrzegane. Geneza problemów związanych z ochroną dzieł sztuki użytkowej (a więc i wzorów przemysłowych) w prawie autorskim wynika w moim przekonaniu właśnie z tego, że pryncypia tej ochrony krystalizowały się w XIX w., który operował rozdwojoną optyką - separująca piękno i użyteczność.

Ochrona rezultatów twórczości intelektualnej, które miały przeznaczenie użytkowe (początkowo deseni na tkaninach, następnie modeli i wzorów stosowanych w przedmiotach przestrzennych), wyprzedziła ochronę prawnoautorska. We Francji i w Wielkiej Brytanii w pierwszej połowie XIX w. rezultaty twórczości intelektualnej dotyczącej przedmiotów użytkowych były chronione w reżimach sui generis, co odpowiadało ówczesnym potrzebom gospodarczym. Przewidziano dla nich formę szczególną - zbliżoną do ochrony typowej dla przedmiotów własności przemysłowej - opartą na rejestracji, krótszą w czasie i bazująca na zobiektywizowanej ocenie wkładu twórczego jako kryterium ochrony. W tym sensie reżim wzorniczy stanowi pierwszy nowoczesny system ochrony przedmiotów tzw. własności intelektualnej ${ }^{25}$, który wykrystalizował się już w pierwszej połowie XIX w. w Wielkiej Brytanii (1839),

${ }^{21}$ Charybda (Chárybdis) jako potwór morski znajdujący się naprzeciwko Scylli pochłaniała ogromne ilości wody morskiej razem z pływającymi po niej statkami.

${ }^{22}$ Nazywanej tė̇ zamiennie sztuką stosowaną. Por. ang. works of applied arts, fr. art industriel, les œuvres des arts appliqués à l’industrie.

${ }^{23}$ Por. ang. fine arts, fr. beaux art, art pur.

${ }^{24}$ Jak podobno mawiał Sokrates: „nawet tarcza wykonana ze złota jest brzydka, jeżeli pod kątem przydatności nie jest tak wykonana, jak trzeba, a kosz do śmieci jest piękny, jeśli jest zrobiony tak, jak trzeba. [...] Wszystko bowiem jest dobre i piękne ze względu na swą użyteczność" (Ksenofont, Wspomnienia o Sokratesie III, 8, w: idem, Pisma sokratyczne, tłum. L. Joachimowicz, Warszawa 1967).

${ }_{25}$ Tak L. Bently, Requiem for Registration? Reflections on the History of the UK Registered Designs System, w: A. Firth (red.), The Prehistory and Development of Intellectual Property Systems, Perspectives on Intellectual Property Series, London 1997, s. 3. 
zanim jeszcze prawo autorskie i prawo patentowe przybrały formę zorganizowanych systemów ochrony i od 150 lat ma mniej więcej taki sam kształt ${ }^{26}$.

Tymczasem radykalnie zmieniło się otoczenie wzorów w systemie ochrony własności intelektualnej, tj. reżimy patentowy i prawnoautorski, kwitnące pod koniec XIX w. Ekspansja ich zakresu przedmiotowego oraz treści ochrony zaczęła stanowić podstawowe źródło nakładania się ochrony (kumulacji), a w konsekwencji redukcji znaczenia reżimu wzorniczego $\mathrm{w}$ całym systemie własności intelektualnej. Niestety nie zapobiegły tym zjawiskom dwie wielkie konwencje międzynarodowe, które wobec narastajacych różnic w ustawodawstwach krajowych pominęły problem ustalenia jednolitych standardów ochrony wzornictwa w prawie autorskim i w reżimie sui generis. Konwencja berneńska wyraźnie delegowała kwestię zakresu i zasad ochrony tzw. sztuki użytkowej państwom członkom, ograniczyła jednak okres ochrony prawnoautorskiej dzieł sztuki użytkowej do 25 lat i oderwała go od długości życia twórcy.

W próbach rozgraniczenia domen obu reżimów najszybciej skapitulowali Francuzi, którzy uznali, że wszelkie kryteria delimitacji ${ }^{27}$ są w istocie arbitralne i niesprawdzalne. Zaakceptowali ogłoszoną w 1911 r. teorię Pouilleta o jedności sztuki - która zakładała, że prawo autorskie powinno mieć jednakowe zastosowanie do wszystkich dzieł - zarówno pięknych, jak i użytkowych. Skutkiem nadinterpretacji poglądów Pouilleta jest właściwa systemowi francuskiemu pełna kumulacja ochrony prawnoautorskiej i ochrony sui generis wzorów w prawie francuskim. Jednakże w większości systemów prawnych podjęto próbę wprowadzenia mechanizmów, które będą zabezpieczały przed negatywnymi skutkami krzyżowania się zakresów przedmiotowych ochrony prawnoautorskiej i wzorniczej. W Wielkiej Brytanii jeszcze do niedawna obowiązywał Sec. 52 Copyright, Design and Patent Act z 1988 r, który ograniczał zakres ochrony prawnoautorskiej w przypadku multiplikacji utworu w liczbie przekraczajacej 50 egzemplarzy. Włosi stosowali kryterium dysocjacji - co przez lata uniemożliwiało im ochronę wzornictwa w prawie autorskim. Niemcy zaś, dostrzegając w reżimie wzorniczym podbudówkę prawa autorskiego, by zapobiec podwójnej ochronie tego samego rezultatu kreacji, stosowali względem wzornictwa podwyższone wymogi dotyczące natężenia cech twórczych (Gestaltungshöhe), czego nie czyniono względem innych utworów chronionych w prawie autorskim.

Wiek XX przyniósł jednak swoje zmiany i wyzwania, na które musiał jakoś zareagować system prawny. Przede wszystkim w XX w. estetyka i funkcja znów zostały zintegrowane, na pojęcie sztuki zaś wpływ zaczęły mieć: konsumeryzm, masowy odbiór, strategie rynkowe ${ }^{28}$, co zaowocowało obecna w drugiej połowie XX w. tendencją do rozszerzania zakresu przedmiotowego

${ }^{26}$ Ibidem, s. 14.

${ }_{27}$ Francuzi początkowo stosowali rozmaite kryteria delimitujące obie dziedziny własności intelektualnej (badali sposób reprodukcji, cel i przeznaczenie utworu, status twórcy, przewagę cech artystycznych lub użytkowych, oceniali wartość artystyczną, zamiar twórcy).

${ }_{28}$ Zob. U. Suthersanen, Function, Art and Fashion: Do We Need the EU Design Law?, w: Ch. Geiger (red.), Constructing European Intellectual Property: Achievements and New Perspectives, Cheltenham-Northampton 2013, s. 356. 
ochrony prawnoautorskiej. Prawo autorskie przestało być prawem kultury, stało się raczej prawem przemysłu wykorzystującego kreacje kulturalne ${ }^{29}$. Konstytucyjny dla całej dziedziny własności intelektualnej podział na własność literacka i artystyczna, własność techniczną i własność związaną ze sfera oznaczenia stracił na ostrości. Nastapiła erozja granic między poszczególnymi reżimami ochrony i współcześnie w przypadku wątpliwości co do właściwego przyporządkowania wytworu intelektualnego nie można już odwołać się do ontologicznie odmiennego przedmiotu ochrony.

$\mathrm{Na}$ tle zjawisk XX w. ważnym historycznie momentem w ustalaniu miejsca ochrony przedmiotów użytkowych w prawie własności intelektualnej jest dokonana pod koniec lat dziewięćdziesiątych europeizacja prawa wzorów. Twórcom jednolitego prawa wzorów przemysłowych w Europie przyświecała idea usamodzielnienia ochrony wzorów. Żywili oni głębokie przekonanie, że atrakcyjność tej formy ochrony zminimalizuje problem delimitacji z ochrona prawnoautorska. Jak pokazał czas, wiara, że atrakcyjność reżimu wzorniczego przebije atrakcyjność ochrony prawnoautorskiej, była jednak złudna, by nie rzec - naiwna.

Twórcy koncepcji unijnej prawa wzorów wyszli od podstawowego rozróżnienia celów ochrony prawnoautorskiej i wzorniczej ${ }^{30}$. Serce ochrony prawnoautorskiej spoczywa w więzi twórcy z utworem, ta więź jest czynnikiem decydującym o przyznaniu ochrony prawnoautorskiej. Wyrazem tej szczególnej więzi między twórcą a utworem jest ochrona autorskich praw osobistych oraz związanie okresu ochrony z długością życia twórcy. Natomiast ochrona wzornicza jest przyznawana ze względu na wartość wzoru jako instrumentu marketingowego. O przyznaniu tej ochrony decyduje odbiór wzoru przez zorientowanego użytkownika - normatywny model przeciętnego, acz zorientowanego w stanie wzornictwa odbiorcy. W konsekwencji kryteria ochrony wzorniczej zostały zaprojektowane jako co do istoty inne aniżeli warunki dostępu do ochrony prawnoautorskiej ${ }^{31}$.

W chwili uchwalania dyrektywy 98/71/WE kryteria ochrony prawnoautorskiej były niezharmonizowane w UE. Dlatego, by nie otwierać puszki Pandory, jaką okazałoby się ujednolicanie wymogów ochrony prawnoautorskiej wzorów przemysłowych, przyjęto art. 17 ust. 2 pr.aut. Sytuacja zmieniła się jednak radykalnie w ciagu ostatnich lat i obecnie kryterium „oryginalności” może być traktowane jako ujednolicone w ramach linii orzeczniczej TSUE, rozpoczętej wyrokiem w sprawie Infopaq ${ }^{32}$ i rozwijanej w kolejnych orzeczeniach. Trybunał formule „własnej twórczości intelektualnej autora”, która była kryterium ochrony sformułowanym przez prawodawcę w odniesieniu do wybranych i granicznych przedmiotów, takich jak programy komputerowe, fotografie i bazy

${ }_{29}$ Tak M. Leistner, G. Hansen, Die Begründung des Urheberrechts im digitalen Zeitalter Versuch einer Zusammenführung von individualistischen und utilitaristischen Rechtfertigungsbemühungen, „Gewerblicher Rechtsschutz und Urheberrecht” 2008, z. 6, s. 479.

${ }^{30}$ Tak obrazowo różnicę tę zilustrowała A. Kur, The Green Paper's "Design Approach" - What's Wrong with It?, „European Intellectual Property Review” 15, 1993, nr 10, s. 377.

31 Ibidem, s. 377.

${ }^{32}$ Wyrok z 16 lipca 2009 r. w sprawie C-5/08, Infopaq International A/S v Danske Dagblades Forening, Zb. Orz. 2009, I-06569. 
danych, nadał walor uniwersalny ${ }^{33}$. W konsekwencji obecnie pojęcie „własnej twórczości intelektualnej” stało się kryterium otwartym, niezwiązanym z kategoriami twórczości, a więc znajdującym zastosowanie również do dzieł sztuki użytkowej (tu: wzorów przemysłowych). W kolejnych wyrokach TSUE dodaje wskazówki dotyczące rozumienia tej formuły (wypełnia ją treścia), podkreślając, że oceny mają uwzględniać wolność twórcy, piętno osobiste, a przede wszystkim wolne i twórcze wybory (to, jaki użytek twórca zrobił z dostępnego mu zakresu swobody). Dodatkowo Trybunał w wyroku w sprawie Flos ${ }^{34}$ wyraźnie ocenił wszelkie mechanizmy krajowe ograniczające dostęp do ochrony prawnoautorskiej jako sprzeczne z art. 17 dyrektywy 98/71/WE.

Ta linia orzecznicza spowodowała usunięcie w regulacjach krajowych normatywnych mechanizmów limitujących dostęp do ochrony prawnoautorskiej wzorów przemysłowych ${ }^{35}$. Zareagowało na nią również orzecznictwo krajowe. Sądy włoskie zaczęły stwierdzać spełnienie wymaganego przez ustawę kryterium wartości artystycznej (wł. valore artistico) w przedmiotach, które w odbiorze krytyki artystycznej, instytucji kultury, muzeów są sztuką. Bardzo pomocnym czynnikiem stało się wystawienie przedmiotu (najczęściej ikony designu) w muzeum. W orzecznictwie niemieckim odrzucono stosowany przez lata w odniesieniu do utworów o charakterze użytkowym podwyższony wymóg dotyczący cech twórczych (niem. Gestaltungshöhe) jako niezgodny z unijna zasada samodzielności ochrony wzorów w reżimie wzorniczym ${ }^{36}$. Orzecznictwo niemieckiego Federalnego Trybunału Sprawiedliwości (BGH) podkreśla współcześnie, że w ocenach należy skupić się na ustaleniu, czy mamy do czynienia z kreacją artystyczna w odbiorze grona zaznajomionego (obeznanego) ze sztuka ${ }^{37}$. Wystawienie obiektu w muzeum może być potwierdzeniem występowania cechy oryginalności w utworze. Odmawia się natomiast ochrony, gdy twórca wykorzystał czysto techniczny zakres swobody, który nie pozwala na osiagnięcie artystycznej jakości ${ }^{38}$. W zagranicznych orzeczeniach pojęcie kreacji artystycznej zdaje się, że jest wykorzystywane jako pomoc w ograniczeniu hipertrofii ochrony prawnoautorskiej w dużym stopniu spowodowanej kształtowaniem się unijnych podwalin tej ochrony.

W Polsce problem ochrony sztuki użytkowej w prawie autorskim przedstawia się następująco. Wciąż obowiązuje art. 116 p.w.p. - przepis ograniczajacy treść autorskich praw majątkowych przysługujacych uprawnionemu po wygaśnięciu prawa z rejestracji wzoru przemysłowego. Wobec reakcji innych państw członkowskich na wyrok w sprawie Flos zastanawiajacy jest brak poważnej debaty na temat zgodności tego przepisu z prawem UE i Konwencja

${ }^{33}$ Zamiast wielu zob. S. von Lewinski, Introduction: The Notion of Work under EU Law, „Gewerblicher Rechtsschutz und Urheberrecht. Internationaler Teil” 2014, z. 12, s. 1098 i n.

34 Zob. wyrok TSUE z 27 stycznia 2011 r. w sprawie C-168/09 (Flos), [2011] Zob. Orz., I-00181.

35 Zob. reakcję w ustawodawstwie Wielkiej Brytanii i Włoch.

${ }^{36}$ Zob. wyrok BGH z 13 listopada 2013 r., I ZR 143/12 (Geburtstagszug), „Gewerblicher Rechtsschutz und Urheberrecht” 2014, z. 2, s. 175.

37 Ibidem.

${ }^{38}$ Zob. wyrok BGH z 12 maja 2011 r., I ZR 53/10 (KG) Seilzirkus, „Gewerblicher Rechtsschutz und Urheberrecht” 2012, z. 1, s. 58, w którym przyjęto, że w przypadku przedmiotów użytkowych ochroną prawnoautorską jako dzieła sztuki użytkowej mogą być objęte tylko cechy, które nie sa uwarunkowane technicznie, lecz zostały ukształtowane w sposób twórczy. 
berneńską ${ }^{39}$. Jednakże o wiele bardziej niepokojące są wypowiedzi Sądu Najwyższego dotyczące spełnienia kryteriów ochrony prawnoautorskiej ${ }^{40}$. Pokazują one, że logika prawa własności przemysłowej zagościła w prawie autorskim bez refleksji nad konsekwencjami dla całego systemu chroniącego własności intelektualna, a także dla rynku i konkurencji.

Dla omawianej tu problematyki znaczący jest w szczególności wyrok Sądu Najwyższego z 6 marca 2014 r. (V CSK 202/13) dotyczący prawnoautorskiej ochrony projektu znicza. Znicz, którego ochronę prawnoautorską rozważał Sąd, tworzyły następujące elementy: pojemnik zbudowany z trzech form przestrzennych o kształcie walca (kołnierz, trzon, podstawa), stożkowe pierścienie przy kołnierzu i podstawie, czerwony kolor, gładki półprzezroczysty materiał pojemnika, metalicznie złoty kolor gładkiej przykrywki i jej proporcje $(1: 2,5)$ oraz geometryczny ornament na obwodzie przykrywki. Projekt znicza jako rozwiązanie dotyczące postaci produktu ukształtowanej przez cechy wzornicze (linii, kształtu, kolorystyki), a więc wzór przemysłowy, może stanowić dzieło sztuki użytkowej.

Projekt (wzór) znicza poza cechami postaci, które w oczach odbiorców powinny być wizualnie atrakcyjne, ma spełniać bardzo konkretne zadania użytkowe. Weryfikacja spełnienia kryteriów ochrony prawnoautorskiej powinna w przypadku tego rodzaju wytworów uwzględniać po pierwsze stwierdzenie, że jest to przejaw działalności twórczej, a więc ustalenie, iż stanowi on rezultat kreacji intelektualnej. Już na tym etapie spod ocen powinny zostać wyłączone te cechy wytworu, które nie są wynikiem działań o charakterze twórczym, a więc ogólnie znane i dostępne cechy, idee leżące u podstaw pewnych rozwiązań czy cechy znalezione w zasobie rozwiązań już znanych ${ }^{41}$, tzw. object trouvé (w przypadku znicza - forma kolumnowa czy przykrywka z motywem krzyża). W projektowaniu wzornictwa przemysłowego istotne znaczenie ma stosowanie pewnych stałych schematów i sposobów komunikacji właściwych dla tej dziedziny oraz branży produktów. Skutkuje to wyłączeniem spod ochrony prawnoautorskiej takich cech (określanych w języku angielskim jako commonplace or standardised features $)^{42}$. W przypadku znicza wyłaczony spod ochrony jest zarówno materiał użyty do wytworzenia produktu, jak i jego kolor. Trudno uznać za rezultat kreacji intelektualnej wybór czerwonego koloru dla znicza.

\footnotetext{
${ }^{39}$ Zgodnie z art. 1 pkt 24 ustawy z 12 czerwca 2015 r. o zmianie ustawy - Prawo własności przemysłowej oraz niektórych innych ustaw art. 116 zostanie uchylony.

${ }_{40}$ Zob. wyrok SN z 25 stycznia 2006 r., I CK 281/05, OSNC 2006, nr 11, poz. 186, w którym SN dopatrzył się oryginalnego układu tarcz obrotowych liczników kalorii; wyrok SN z 27 lutego 2009 r., V CSK 337/08, OSP 2010, nr 3, poz. 33, dotyczacy ochrony prawnoautorskiej specyfikacji istotnych warunków zamówienia traktowanej jako kategoria „dzieła referencyjnego”; wyrok SN z 19 lutego 2014 r., V CSK 180/13, Legalis, dotyczacy kwestii współautorstwa utworu „elektroniczny system konstatowania czasu przylotu gołębi”, w którym założono jego ochronę prawnoautorską w ramach szerokiej kategorii „dzieła technicznego”.

${ }^{41}$ Który sąd zdaje się określać mianem domeny publicznej. K.-N. Peifer ("Individualität” or Originality? Core Concepts in German Copyright Law, „Gewerblicher Rechtsschutz und Urheberrecht, Internationaler Teil” 2014, z. 12, s. 1102) wskazuje, że nie ma ochrony tzw. object trouvé - przedmiotów znalezionych, a nie samodzielnie ukształtowanych przez twórcę, użytych z uwagi na ich wartość estetyczną.

${ }^{42}$ Zob. U. Suthersanen, Design Law: European Union and United States of America, wyd. 2 , London 2010, s. 243.
} 
W szeregu orzeczeń zagranicznych już na tym wstępnym etapie wyłącza się spod możliwości ochrony w prawie autorskim rezultaty kreacji intelektualnych o charakterze technicznym, funkcjonalnym jako niestanowiace wytworów działalności intelektualnej, dla których można poszukiwać ochrony w domenie prawa autorskiego. Czyni się to również za pomocą rozróżnienia między niechronioną ideą i chronionym sposobem wyrażenia (idea/expression dichotomy), zarysowanego $\mathrm{w}$ polskim prawie w art. $2^{1}$ pr.aut. ${ }^{43}$ Wydaje się, że de lege lata na gruncie definicji zawartej w art. 1 ust. 1 pr.aut. nie ma podstaw do zawężania dostępności tej ochrony do utworów o charakterze artystycznym, choć mogłoby to być do pewnego stopnia skuteczne narzędzie ograniczenia „zachłanności” prawa autorskiego.

Dostęp ochrony prawnoautorskiej kreacji użytkowych limitowany jest na drugim etapie rozważań ograniczającym się do oceny, czy przejaw działalności twórczej ma w konkretnym przypadku indywidualny charakter. Weryfikacja tej cechy wymaga przede wszystkim ustalenia zakresu swobody twórczej, którym dysponował twórca, podejmując się stworzenia utworu w konkretnej dziedzinie. Określenie ram tej swobody (często z pomocą biegłego) może pozwolić sądowi na stwierdzenie, czy w konkretnym przypadku wybory twórcy były rzeczywiście wolne, a nie podyktowane względami funkcjonalnymi, technicznymi, marketingowymi itd. Zwykła odmienność wytworu na tle wcześniejszych kreacji nie wystarcza do stwierdzenia indywidualności (oryginalności) wymaganej w prawie autorskim ${ }^{44}$. W rezultatach wyborów twórczych powinno być dostrzegalne piętno osobiste. Ten czynnik uwzględnia ocenę jakościowa, pozwalająca na ustalenie minimalnego poziomu indywidualnego charakteru (zwanego zamiennie oryginalnościa), który sąd w konkretnym przypadku uznaje za konieczny.

W przypadku rozwiązań czysto technicznych czy funkcjonalnych (np. kształt maszyny) możemy mieć do czynienia z wolnymi wyborami twórczymi oraz ze statystyczną jednorazowością kreacji. Wybory projektanta takich przedmiotów moga być swoiście twórcze, ale nasuwa się pytanie, czy jest to twórczość, jakiej wymaga prawo autorskie ${ }^{45}$. Jak jednak uzasadnić w takim przypadku -

${ }^{43}$ Zob. wypowiedź TSUE w sprawie C-393/03 (BSA), iż „kryterium oryginalności nie jest spełnione, jeśli sposób wyrażenia tych elementów jest podyktowany ich funkcja techniczna, ponieważ różne sposoby wyrażenia zamysłu są tak ograniczone, że sam zamysł i jego wyraz spajają się $\mathrm{w}$ jedno (ang. the idea and the expression become indissociable). Zob. też wyrok z 2 maja 2012 r. w sprawie C-406/10 (SAS Institute), zgodnie z którym funkcjonalność programu nie jest chroniona.

${ }^{44} \mathrm{~W}$ analizowanym wyroku Sąd przyjął inaczej: „Ze stanowiska Sądu drugiej instancji, który podzielił ocenę Sądu pierwszej instancji opartą na opinii biegłego prof. J. O., jednoznacznie wynika, że wzór znicza w chwili jego powstania wyraźnie różnił się od innych zniczy, a więc posiadał cechę indywidualności w dostatecznym natężeniu odróżniającym go od innych tego rodzaju wytworów. Dodać należy, iż prawidłowości takiej oceny Sądu Apelacyjnego nie podważało to, że autor wzoru znicza posłużył się przy jego projektowaniu znaną od wieków prostą formą kolumnowa, a więc elementami nie mającymi cech nowości obiektywnej”.

${ }_{45}$ Tak A. Quaedvlieg, The Tripod of Originality and the Concept of Work in Dutch and European Copyright, „Gewerblicher Rechtsschutz und Urheberrecht, Internationaler Teil” 2014, z. 12, s. 1106. 
skądinąd intuicyjnie trafną - decyzję o odmowie ochrony? Wydaje się, że ta bezsilność normatywna jest i będzie wykorzystywana do zapewnienia ochrony prawnoautorskiej szeregu tego typu rozwiązań (wydaje się również, że w tę pułapkę wpadł SN w przypadku znicza). Ostatnią deską ratunku zdaje się w takich przypadkach końcowy element oceny, mianowicie ocena aksjologiczna, uwzględniająca znaczenie przyznania ochrony prawnoautorskiej dla wolnej konkurencji oraz domeny publicznej.

Sąd I instancji, stwierdzając ochronę prawnoautorska, uzasadnił ją powstaniem znicza dzięki samodzielnemu wysiłkowi twórczemu, jego oryginalnością i cechą nowości oraz faktem, że produkt pozwanego jest na tyle podobny do znicza powoda, iż przeciętny odbiorca zostaje wprowadzony w błąd co do pochodzenia wyrobu, a pozwany, wprowadzając swój produkt na rynek, w sposób nieuczciwy i sprzeczny z dobrymi obyczajami wykorzystuje dorobek powoda. Od początku więc sąd niejako scalił w jedno kryteria ochrony prawnoautorskiej oraz zasady zwalczania nieuczciwego naśladownictwa, sądy wyższych instancji zaś nie dokonały gruntownej korekty tego grzechu pierworodnego ${ }^{46}$.

Sąd kasacyjny, potwierdzając trafność rozstrzygnięć sądów niższej instancji, relacjonuje wypracowane dotychczas w piśmiennictwie i orzecznictwie sposoby oceny wystapienia w wytworze cechy indywidualności. Przytacza nawet wyrok TSUE w sprawie Painer ${ }^{47}$, który wyróżnia się na tle orzecznictwa dotyczącego kryterium oryginalności wyraźnym wskazaniem na znaczenie piętna osobistego twórcy, które powinno być zauważalne w jego twórczych wyborach. $\mathrm{W}$ istocie jednak $\mathrm{w}$ wyroku tym, mimo odwołania do definicji zawartej $\mathrm{w}$ art. 1 ust. 1 pr.aut., SN decyduje o przyznaniu ochrony prawnoautorskiej kreacji o charakterze użytkowym na podstawie kryteriów właściwych prawu własności przemysłowej, tj. różnicy między ocenianym rezultatem pracy intelektualnej a stanem wzornictwa $\mathrm{w}$ danej dziedzinie ${ }^{48}$, co zamazuje dystynkcje między zasadami przyznawania ochrony w obu dziedzinach ${ }^{49}$. Różnica tego rodzaju stanowi kryterium ochrony w reżimie wzorniczym. Zdaniem biegłego, przytoczonym w uzasadnieniu wyroku, postać znicza „uwarunkowana jest przyjętym przez twórcę wzoru intelektualnym założeniem projektowym mającym spełniać estetyczne, jego lub wybranej grupy klientów, wymagania (preferujących wybraną stylistykę wyrobu)". Czyż biegły nie miał na myśli grona zorientowa-

46 Problem, czy odtworzenie formy znicza stanowiło naśladownictwo nieuczciwe w świetle art. 13 ustawy z 16 kwietnia 1993 r. o zwalczaniu nieuczciwej konkurencji (Dz. U. 2003, Nr 153, poz. 1503 ze zm), zasługuje na odrębną dyskusję. Konieczna jest bowiem analiza, czy znicz posiada cechę konkurencyjnej indywidualności (swoistości) i czy jego naśladownictwo faktycznie wprowadzało odbiorców w błąd co do pochodzenia od konkretnego przedsiębiorcy (zob. więcej w tej kwestii A. Tischner, Zakaz nieuczciwego naśladownictwa w ustawie o zwalczaniu nieuczciwej konkurencji a ochrona postaci produktu w prawie własności przemysłowej, „Kwartalnik Urzędu Patentowego RP” 2013, nr 5, s. 110 i n.). I w tym zakresie wywody SN są bardzo lakoniczne, dowodzą braku zrozumienia istoty zwalczania nieuczciwego naśladownictwa.

${ }^{47}$ Wyrok z 1 grudnia 2011 r. w sprawie C-145/10 (Eva-Maria Painer), pkt 92.

${ }^{48}$ Nieprawidłowo określając zasób wzorów mianem domeny publicznej, co dowodzi niezrozumienia istoty obu pojęć.

${ }^{49} \mathrm{~W}$ uzasadnieniu przytoczony został wcześniejszy wyrok SN z 13 stycznia 2006 r., III CSK 40/05: „Nie może być uznany za utwór i objęty ochroną prawa autorskiego taki przejaw ludzkiej aktywności umysłowej, któremu brak cech dostatecznie indywidualizujących, to jest odróżniających go od innych wytworów podobnego rodzaju i przeznaczenia”. 
nych użytkowników, dla których postać produktu ma znaczenie przy decyzji o jego zakupie, co stanowi przedmiot oceny w ramach weryfikacji indywidualnego charakteru wzoru przemysłowego?

Wydaje się, że powołany w sprawie biegły z zakresu wzornictwa przemysłowego ${ }^{50}$ wydał opinię, oceniajac zakres swobody twórczej analizowany z punktu widzenia projektanta wzorów przemysłowych, któremu postawiono zadanie stworzenia projektu konkretnego produktu zaspokajającego konkretne potrzeby odbiorców. W opinii, która była podstawą rozstrzygnięcia o spełnieniu kryteriów ochrony prawnoautorskiej, wyszczególniono szereg różnic ocenianego wzoru znicza, dotyczących m.in. zestawień i połączeń elementów form przestrzennych (pojemnika i przykrywki) odróżniających go od innych form zniczy dostępnych na rynku, a więc - zdaniem sądu - potwierdzajacych cechę indywidualności ${ }^{51}$. Biegły podkreślił, że wzór znicza „wyraźnie różnił się od innych zniczy, a więc posiadał cechę indywidualności w dostatecznym natężeniu odróżniającym go od innych tego rodzaju wytworów".

Sąd Najwyższy wskazał w uzasadnieniu, że: „w odniesieniu do wytworów o charakterze użytkowym, przyjmowano w orzecznictwie, że osiagnięty rezultat - który nie jest zdeterminowany przyjętymi założeniami funkcji użytkowych - musi istotnie (dostatecznie, wyraźnie, szczególnie, widocznie, wyraziście, doniośle, charakterystycznie) odróżniać się od innych, podobnego rodzaju wytworów. Podzielając to stanowisko, wyrażające w istocie tę sama myśl, ale za pomocą różnych, ale znaczeniowo tożsamych desygnatów słownych, należy mieć na uwadze, że użytkowy charakter wytworu oznacza, iż musi on spełniać pewne z góry określone cechy, jak też być podporządkowany określonym cechom standardowym, co niewątpliwie utrudnia ocenę istnienia cechy indywidualności. Istotne sa więc różnice ocenianego wytworu z podobnymi wytworami należącymi do domeny publicznej ${ }^{52}$. W takich przypadkach zawsze zachodzi konieczność odwołania się przez sąd rozstrzygający spór do ocen wartościujących z uwzględnieniem ustaleń dokonanych w sprawie przy wykorzystaniu dowodu z opinii biegłego". Sąd nie wyjaśnił jednak, na czym w jego przekonaniu oceny wartościujace mają polegać i jakie czynniki należy uwzględniać. W istocie ocen tych w omawianej sprawie zabrakło.

Sąd, jak się wydaje, nie zdał sobie sprawy ze skutków rozstrzygnięcia stwierdzającego ochronę prawnoautorską tego rodzaju wytworu. Jaki skutek ma zakwalifikowanie znicza o tak minimalnym poziomie indywidualności dla zakresu jego ochrony? ${ }^{53}$ Czy w przyszłości każdy przedsiębiorca, który wybie-

50 Choć wyroki są anonimizowane, zbieżność inicjałów biegłego w obu analizowanych tu wyrokach SN sygnalizuje, że ten sam specjalista został powołany przez Sąd do wydania opinii na temat spełnienia kryteriów ochrony prawnoautorskiej i ochrony prawem z rejestracji wzoru przemysłowego.

51 Zob. uzasadnienie wyroku, s. 17.

${ }^{52} \mathrm{Na}$ marginesie należy zauważyć, że w całym wyroku SN posługuje się pojęciem domeny publicznej, nie rozumiejąc, jak się wydaje, jego znaczenia.

${ }^{53} \mathrm{Na}$ niebezpieczne skutki przyznawania ochrony prawnoautorskiej w takich przypadkach zwraca uwagę A. Quaedvlieg, komentując wyrok sądu holenderskiego w sprawie ikony designu - krzesełka Tripp-Trapp, którego indywidualny charakter konstytuowany był przez kształt pochylonej litery L. Autor konstatuje: „Via this mechanism, weak copyright elements create large copyright protection" (zob. idem, op. cit., s. 1109). 
rze dekiel tego kształtu narazi się na naruszenie prawa autorskiego do znicza? Czy już skopiowanie kształtu krzyża na tym deklu - chrześcijańskiego symbolu niepodlegającego zawłaszczeniu - wystarczy? Czy każde odtworzenie formy kolumnowej (np. w wazonie czy kubku) będzie ingerować w prawa autorskie powoda? A co w sytuacji, gdy wszystkie wyżej wspomniane cechy będą inkorporowane do znicza, który będzie stanowić rezultat niezależnej twórczości? Czy każdy z tych projektantów będzie twórcą niezależnie chronionym w prawie autorskim? Jaki będzie wówczas zakres ochrony?

Nasuwa się pytanie o znaczenie tego rodzaju rozstrzygnięcia dla rynku tego typu produktów w Polsce. Wydaje się, że powodowi chodziło o osiagnięcie skutku podobnego do tego, który można osiąnąć za pomocą praw własności przemysłowej. Takie permisywne podejście SN wywoła z pewnością lawinę spraw, w których ochrona prawnoautorska będzie orężem w walce z konkurentami oferujacymi produkty substytucyjne, a ochrona sui generis wzornictwa przemysłowego okaże się zbędna. Na przykładzie dzieł sztuki użytkowej (tu: wzorów przemysłowych) doskonale widać, że prawo autorskie skonsumowało to, do czego została stworzona ochrona sui generis (rezim wzorniczy) oparta na obiektywnych kryteriach, ale ograniczona w czasie, co jest bardzo szkodliwe dla spójności systemu ochrony własności intelektualnej. Jeżeli odbiór zorientowanego użytkownika wystarcza do stwierdzenia oryginalności, to tracimy uzasadnienie ochrony sui generis.

Ochrona sui generis nie ma ambicji objęcia swym zakresem całości interesów związanych z postacią przedmiotów, którym przypisane są również cele utylitarne. Ochrona w reżimie wzorniczym przyznawana jest przez wzgląd na szczególną wartość designu polegającą na zdolności promowania sprzedaży produktów. Palace jest jednak pytanie, o uzasadnienie ochrony prawnoautorskiej wzornictwa przemysłowego (sztuki użytkowej) współcześnie, a także pytanie o miejsce ochrony prawnoautorskiej w całym systemie prawa własności intelektualnej oraz dokąd zmierza prawo autorskie w XXI w. Jądro ochrony stanowi przecież więź twórcy z utworem, a wyrazem tej więzi jest ochrona autorskich praw osobistych i związanie okresu ochrony z długością życia twórcy. W zagranicznych wyrokach, jako reakcję na ciagłe rozszerzanie domeny prawa autorskiego, dostrzegamy próbę powrotu do ocen wartości artystycznej utworów, co w przyszłości może wręcz prowadzić do wykształcenia się modelu normatywnego „znawcy sztuki” czy ,zorientowanego odbiorcy sztuki” jako relewantnego dla oceny oryginalności.

Ze względu na naturalne i nieprzezwyciężalne trudności w ujęciu przedmiotu ochrony prawnoautorskiej w język pojęć prawnych powinniśmy jednak zastanowić się przede wszystkim, dlaczego chcemy chronić pewne rezultaty wysiłku intelektualnego w sposób taki, jak określa to prawo autorskie (przez tak długi okres, z taką mocą i tak wszechstronnie). Współcześnie prawo autorskie jest wykorzystywane przez podmioty gospodarcze w celu uniemożliwiania wprowadzania na rynek produktów podobnych (substytucyjnych i konkurencyjnych). Skoro tak się dzieje, to ten interes - interes konkurentów oraz interes ogólny (polegający na swobodzie podejmowania działalności i wolności konkurencji), ale również interes innych twórców wyrażający się w wolności 
czerpania z zasobów, które nie powinny podlegać monopolizacji w formie prawa autorskiego (a więc cech użytkowych, funkcjonalnych, typowych, od lat znanych - jak choćby forma kolumnowa), należy uwzględniać przy rozstrzyganiu o spełnieniu kryteriów tej ochrony ${ }^{54}$. Tymczasem za pomoca pojęć wysokich i niedookreślonych, tj. piętno osobiste, przejaw działalności twórczej, twórcze wybory, feruje się wyroki o tak dużym wpływie na rynek. Wykładnia wymogu indywidualnego charakteru w prawie autorskim powinna uwzględniać potrzebę ochrony domeny publicznej jako skarbnicy inspiracji dla przyszłych pokoleń twórców oraz potrzeby konkurencji.

Jako antidotum na subiektywizm i arbitralność ocen oryginalności utworu oraz trudności w uniknięciu ocen wartości utworu Christophe Geiger proponuje zastosowanie testu trójstopniowego, wywodzącego się z amerykańskiej doktryny fair use, który stanowiłby warunek wstępny ochrony prawnoautorskiej utworu ${ }^{55}$. Zdaniem autora powinien on przyjąc formę klauzuli, która mogłaby być wskazówką dla sędziów weryfikujacych indywidualny charakter (oryginalność) utworu. Test ten powinien przyjąć następującą formułę: ochronie prawnoautorskiej podlega przejaw stanowiący rezultat działań twórczych (I warunek), w przypadku których zakres swobody twórczej był większy aniżeli zewnętrzne ograniczenia (II warunek), z uwzględnieniem negatywnego wpływu przyznania ochrony na przyszłą twórczość oraz wystapienia nieuzasadnionej szkody dla uzasadnionych interesów publicznych (III warunek) ${ }^{56}$.

Bardzo niepokojąca jest tendencja do dostrzegania przejawów twórczości zasługującej na ochronę w każdym rezultacie pracy człowieka, bez refleksji na temat jej skutków. To co przystoi adwokatom, nie zawsze przystoi sądom, które w przypadku ochrony prawnoautorskiej są czynnikiem prawotwórczym w tym sensie, że istnienie tej ochrony w konkretnym przypadku zależy w istocie i w całości od prawomocnego wyroku sądu ${ }^{57}$. Sąd każdorazowo powinien zdawać sobie sprawę z odpowiedzialności za swoje działania i konsekwencji, jakie pociaga za sobą stwierdzenie przejawu działalności twórczej o indywidualnym charakterze, które blokuje rynek na bardzo długi czas i toruje drogę dla sankcji o dolegliwości nieznanej innym dziedzinom prawa prywatnego ${ }^{58}$. Sądy, robiąc taki użytek z ochrony prawnoautorskiej, czynią z niej mitologiczną Charybdę.

\section{ZAKOŃCZENIE}

Design jest zjawiskiem polimorficznym i integralnym zarazem, system chroniący własność intelektualną zaś jest coraz bardziej rozbudowany i rozczłonkowany. Wzór przemysłowy jako całość nie musi i nie powinien być chro-

${ }^{54}$ Por. Ch. Geiger, Flexibilising Copyright - Remedies to the Privatisation of Information by Copyright Law, „International Review of Intellectual Property and Competition Law” 39, 2008, nr 2, s. 188 i n.

55 Ibidem, s. 191.

56 Ibidem.

57 Trafnie ujmuje to R. Tomkowicz w formułę „good lawyering does not necessarily lead to good law" (idem, Intellectual Property Overlaps, London-New York 2012, s. 20).

${ }^{58}$ Mam na myśli sankcje określone w art. 79 ust. 1 pkt 3 i 4 pr.aut. 
niony w każdym z potencjalnie dostępnych reżimów własności intelektualnej. Wielość dostępnych form ochrony powinna zachęcać do ich niuansowania, przez pytania o cel i uzasadnienie oraz przedmiot i zakres ochrony w każdym z dostępnych reżimów. Reżim wzorniczy nie został powołany do życia po to, by chronić rozwiązania oceniane przez specjalistów z tej dziedziny jako istotne z ich perspektywy, reżim prawnoautorski zaś nie służy ochronie rezultatów wysiłku intelektualnego, które w oczach odbiorców przydają produktowi atrakcyjności komercyjnej.

System chroniący własność intelektualna jawi się współcześnie jako patchwork trudnych do ogarnięcia, a także coraz liczniejszych form i coraz bardziej zniuansowanych i rozbudowanych zasad ochrony. Wobec atomizacji pryncypiów ochrony oraz konieczności uwzględniania ducha i litery prawa unijnego w rozstrzygnięciach na szczeblu krajowym, orzecznictwo sądowe (w szczególności sądów ostatniej instancji) może i powinno stanowić busolę bezcenną dla wszystkich żeglujących po morzu własności intelektualnej. Omawiane powyżej wyroki utrudnią nawigację tym, którzy chcieliby w sposób bezpieczny prowadzić działalność gospodarczą w zaufaniu do racjonalności zasad ochrony własności intelektualnej. Żeglarze próbujacy ominąć niebezpieczeństwa pochodzące od Scylli mogą zostać niemile zaskoczeni przez czyhającą Charybdę.

dr Anna Tischner

Uniwersytet Jagielloński

anna.tischner@uj.edu.pl

INDUSTRIAL DESIGNS BETWEEN SCYLLA AND CHARYBDIS

Summary

Industrial designs are protected under intellectual property law within numerous regimes. This may be perceived as excess protection and provoke attempts to limit the hypertrophy. Recent judgments of the Polish Supreme Court and the Supreme Administrative Court relating to the criteria of copyright and design protection constitute an incentive aimed at verifying certain concepts and interpretations, as these decisions endanger the reasonableness of the protection of creativity by intellectual property law. The decisions show lack of comprehension on the part of the courts of the core concepts of copyright and design protection, which also tend to mix up the criteria. As a consequence of such interpretation, both regimes resemble the mythological sea monsters - Scylla and Charybdis. 
